\title{
SOCIAL SENSING SENSUS PENDUDUK 2020 PADA JEJARING SOSIAL TWITTER
}

\author{
(Social Sensing of 2020 Population Census on Twitter) \\ Aulia Maghfira ${ }^{1}$, Farid Ridho ${ }^{2}$ \\ Politeknik Statistika STIS ${ }^{1}$ \\ Politeknik Statistika STIS ${ }^{2}$ \\ Jalan Otto Iskandardinata No. 64C Jakarta 13330 \\ E-mail: 16.9036@stis.ac.id
}

\begin{abstract}
ABSTRAK
Salah satu hal penting dalam penyelenggaraan kegiatan sensus penduduk 2020 adalah penyebaran informasi. Twitter menjadi media yang cocok digunakan untuk menyebarkan informasi tentang sensus penduduk 2020 karena penyebaran informasi pada twitter tidak terbatas untuk pengikut suatu akun saja melainkan juga pengguna lain yang tidak menjadi pengikutnya. Pengguna twitter dianggap sebagai sensor sosial, dimana pengguna akan menangkap informasi yang didapatkan dari sekitarnya kemudian mengunggahnya ke twitter. Pada penelitian ini, twitter digunakan untuk melihat pola percakapan, arus informasi, dan partisipasi masyarakat terhadap kegiatan sensus penduduk. Analisis deskriptif dan analisis sentimen digunakan untuk melihat pola percakapan. Hasil menunjukkan tren yang fluktuatif. Volume tweet meningkat tajam ketika sensus penduduk online akan berlangsung dan ketika Presiden Jokowi mengirimkan tweet ajakan mengikuti sensus penduduk. Sebagian besar tweet bersentimen netral. Social Network Analysis (SNA) digunakan untuk melihat arus informasi. Hasil menunjukkan terdapat 3 akun yang paling sering diretweet, yaitu akun Jokowi, BPS, dan akun sandalista yang merupakan akun komunitas yang sering mengirimkan tweet yang berisi opini terhadap kebijakan pemerintah. String matching digunakan untuk melihat partisipasi masyarakat terhadap kegiatan sensus penduduk 2020. Hasil menunjukkan bahwa proporsi pengguna yang membuat tweet didominasi oleh pengguna nonBPS sebesar 85,86 persen. Penelitian ini memberikan rekomendasi dan dapat digunakan sebagai bahan evaluasi dalam penyebaran informasi terkait kegiatan sensus penduduk 2020.
\end{abstract}

Kata kunci: sensor sosial, analisis deskriptif, analisis sentimen, string matching, SNA

\section{ABSTRACT}

One of important things in organizing the 2020 population census is the spread of information. Twitter becomes suitable media for disseminating information about 2020 population census because the spread of information on twitter not only limited for followers of an account but also for others who are not followers. Twitter users are considered as social sensor, where users will capture information obtained from their surroundings then upload them to twitter. In this research, twitter will be used to see the conversation patterns, information flow, and public participation towards 2020 population census. Descriptive and sentiment analysis will be used to see the conversation patterns. Result shows that there is fluctuating trend. Tweets volume increase significantly when online population census will take place and when President Jokowi sent a tweet to join the population census. Most tweets have neutral sentiment. Social Network Analysis (SNA) is used to see the information flow. Result shows that there are 3 most retweeted accounts: Jokowi; BPS; and sandalista, which is a community account that often sends tweets that contain opinion about government policy. String matching is used to see the public participation towards 2020 population census. Result shows that the proportion of users who send tweets is dominated by nonBPS users by 85.86 percent. This research provides recommendation and can be used as evaluation materials on the spread of information of the 2020 population census.

Keywords: social sensor, descriptive analysis, sentiment analysis, string matching, SNA

\section{PENDAHULUAN}

Sensus penduduk merupakan salah satu kegiatan pengumpulan data yang dilakukan oleh Badan Pusat Statistik (BPS) yang bertujuan untuk menyediakan data tentang jumlah, komposisi, distribusi, dan karakteristik penduduk. Sensus penduduk 2020 dilaksanakan dalam 2 tahapan, yaitu secara online dan wawancara. Dilansir dari kompas.com, Muhadjir Effendy (2019) 236 
mengatakan bahwa sensus penduduk dapat menghasilkan data yang valid dan kredibel, dan dapat menyediakan parameter demografi dan proyeksi penduduk serta karakteristik penduduk lainnya untuk keperluan proyeksi penduduk dan indikator Sustainable Development Goals (SDG's).

Salah satu hal penting dalam penyelenggaraan kegiatan sensus penduduk adalah penyebaran informasi. Penyebaran informasi mengenai kegiatan sensus penduduk penting untuk dilakukan agar kegiatan tersebut dapat dikenal publik. Publikasi dilakukan melalui beberapa cara, yaitu publikasi resmi, mengunjungi kampus dan sekolah, mengadakan jalan santai, dan mengunggah poster, video, maupun tulisan-tulisan melalui media sosial. Dilansir dari nasional.kompas.com, Deputi Bidang Statistik Sosial BPS Margo Yuwono (2020) mengakui bahwa publikasi sensus penduduk belum sampai pada tingkat masyarakat akar rumput, yang artinya masih banyak masyarakat yang belum mengetahui adanya kegiatan sensus penduduk 2020. Namun, ia menegaskan bahwa berbagai jenis sosialisasi sudah dilakukan, salah satunya melalui akun media sosial pribadi BPS. Meskipun demikian, di salah satu akun pribadi BPS seperti twitter, pengikut yang dimiliki hanya sebanyak 37.200 orang. Twitter menjadi salah satu jejaring sosial yang cocok untuk menyebarluaskan informasi tentang sensus penduduk 2020.

Menurut Walck (2003), twitter merupakan jejaring sosial yang dapat digunakan secara rea/time dan penyebaran informasi di twitter hanya dibatasi pengikut seseorang yang artinya penyebaran informasi tidak terbatas untuk pengikut suatu akun saja melainkan juga pengguna lain yang tidak menjadi pengikutnya. Pengguna twitter di Indonesia dapat dikatakan cukup banyak. Hal tersebut sesuai dengan hasil pubikasi oleh statista.com pada Juli 2020, dimana Indonesia menempati peringkat ke-8 negara degan pengguna twitter terbanyak di dunia yakni sebanyak 11,2 juta penduduk yang menggunakan twitter.

Takeichi, et al. (2014) menyebutkan bahwa twitter dapat menjadi sensor sosial. Sensor adalah sesuatu yang dapat menangkap informasi dari sekitarnya dan menyalurkannya ke bagian lain. Pada twitter pengguna dianggap sebagai sensor, dimana pengguna akan menangkap informasi yang didapatkan dari sekitarnya kemudian mengunggah informasi tersebut ke twitter. Informasi dari pengguna ini kemudian akan disebarkan atau diteruskan dengan cara di-retweet oleh pengguna lain. Hasil dari proses retweet yang bercabang-cabang akan membentuk suatu jaringan tersendiri.

Penelitian terkait yang digunakan sebagai referensi adalah penelitian yang dilakukan oleh Pedersen, S dkk. (2015) dengan judul "Backchannel Chat: Peaks and Throughs in a Twitter Response to Three Televised Debates during the 2014 Scottish Independence Referendum Campaign". Penelitian bertujuan untuk memberikan pemahaman tentang bagaimana twitter digunakan sebagai sarana komunikasi selama adanya tayangan debat politik di televisi. Untuk menjawab tujuan tersebut, peneliti mengidentifikasi puncak penggunaan twitter selama tiga debat berlangsung. Data dikumpulkan berdasarkan hashtag, geotag, dan 300 akun yang memiliki keterkaitan dengan politik dan referendum. Selain itu, penelitian yang dilakukan oleh Takeichi, Y dkk. (2014) dengan judul "Twitter as Social Sensor: Dynamics and Structure in Major Sporting Events" menggunakan twitter sebagai social sensor terhadap Nippon Professional Baseball (NPB) di Jepang. Penelitian fokus terhadap hubungan tweet dan retweet. Data dikumpulkan melalui twitter search API dan dengan menggunakan hashtag.

Berdasarkan uraian di atas, pada penelitian ini twitter digunakan sebagai sensor sosial untuk mendeteksi pola percakapan, arus informasi, dan partisipasi masyarakat terhadap kegiatan sensus penduduk 2020 di jejaring sosial twitter. Pola percakapan yang dimaksud yaitu volume dan tren tweet yang diunggah baik sebelum maupun ketika sensus penduduk online berlangsung dan hasil analisis sentimen terhadap tweet tentang sensus penduduk 2020. Arus informasi dilihat dari visualisasi jaringan retweet. Partisipasi masyarakat dilihat dari proporsi pengguna BPS dan nonBPS yang membuat tweet atau me-retweet tentang sensus penduduk 2020. Penelitian ini diharapkan dapat memberikan rekomendasi dan digunakan sebagai bahan evaluasi dalam penyebaran informasi terkait kegiatan sensus penduduk yang diselenggarakan oleh BPS

\section{METODE}

Penelitian ini menggunakan data twitter yang dikumpulkan dari tanggal 24 Januari 2020 hingga 23 Maret 2020 dengan kata kunci \#sensuspenduduk2020, \#sp2020, \#mencatatindonesia, 
sensus penduduk, dan bps.go.id. Data terkumpul dengan total sebanyak 22.753 tweet. Adapun variabel yang digunakan sebagai bahan analisis adalah sebagai berikut:

Tabel 1. Variabel yang digunakan dalam penelitian

\begin{tabular}{|c|c|c|}
\hline No & Variabel & Keterangan \\
\hline 1 & created_at & Waktu dikirimkannya tweet. \\
\hline 2 & Text & Variabel yang berisi teks tweet. \\
\hline 3 & user_screen_name & Username masing-masing pengguna. \\
\hline 4 & user_name & Display name pengguna. \\
\hline 5 & user_verified & $\begin{array}{l}\text { Jika bernilai "True", maka menunjukkan bahwa akun } \\
\text { pengguna sudah diverifikasi oleh twitter. }\end{array}$ \\
\hline 6 & user_description & Deskripsi akun yang ditulis oleh pengguna (bio twitter). \\
\hline 7 & user_followers_count & Jumlah follower yang dimiliki oleh pengguna. \\
\hline 8 & truncated & $\begin{array}{l}\text { Bernilai "true" jika teks tweet melebihi panjang } 140 \\
\text { karakter, dan bernilai "false" jika teks tweet kurang dari } \\
140 \text { karakter. }\end{array}$ \\
\hline
\end{tabular}

Pengumpulan data dilakukan melalui twitter streaming API dengan menggunakan package tweepy. Tweepy akan mengambil data twitter melalui streaming API, kemudian menyimpan data dalam format json. Setelah data terkumpul, selanjutnya dilakukan preprocessing dan analisis data. Langkah-langkah analisis yang dilakukan pada penelitian ini, dipaparkan sebagai berikut:

1. Data Preprocessing

Setelah data terkumpul, selanjutnya dilakukan preprocessing untuk menghapus hal-hal yang tidak diperlukan dalam analisis. Preprocessing dilakukan terhadap beberapa variabel, yakni variabel teks tweet, username, display name, dan user description. Tahapan preprocessing data yang dilakukan pada teks tweet yaitu:

(1) Menghapus username. Username diawali dengan simbol "@" tidak digunakan dalam analisis sehingga dihilangkan.

(2) Menghapus hashtag. Hashtag diawali dengan simbol "\#". Pada penelitian ini hashtag hanya digunakan sebagai kata kunci pada saat proses pengumpulan data sehingga kemunculannya yang cukup banyak dapat mengganggu analisis selanjutnya.

(3) Menghapus link URL.

(4) Menghapus kode ascii. Kode seperti â,Ë,̇̀,è,ä dihapus karena tidak memiliki arti.

(5) Menghapus simbol, double space, whitespace, dan angka. Tanda baca seperti $\sim$ !@ $\$ \% \wedge \& *()_{-}+=\{\}[] \backslash: ; ;^{\prime \prime \prime \prime \prime \prime<>~ t i d a k ~ d i p e r l u k a n ~ d a l a m ~ a n a l i s i s ~ s e h i n g g a ~ d i h i l a n g k a n . ~}$

(6) Case folding. Merupakan proses mengubah keseluruhan teks menjadi huruf non kapital. Proses ini dilakukan karena python bersifat case sensitive, sehingga kata "Sensus" dan "sensus" akan dianggap dua kata yang berbeda, padahal keduanya memiliki arti yang sama.

(7) Tokenisasi. Digunakan untuk memisahkan kata-kata dalam suatu kalimat menjadi kumpulan kata-kata (bag of words).

(8) Normalisasi. Normalisasi teks merupakan perbaikan kata-kata salah ketik maupun singkatan. Normalisasi teks dilakukan dengan membandingkan masing-masing kata dengan kamus kosakata. Selanjutnya, mengubah kata-kata singkatan maupun salah ketik, seperti "yg" menjadi "yang", "dmn" menjadi "dimana", "kpn" menjadi "kapan", dan lain sebagainya.

(9) Stemming. Stemming digunakan untuk mengubah kata-kata pada teks menjadi kata bakunya. Misalnya, "mengubah" menjadi "ubah", "mengisi" menjadi "isi', dan lain sebagainya.

(10) Menghapus stopword. Setelah melalui semua tahap di atas, preprocessing dilanjutkan dengan penghapusan stopwords atau kata penghubung. Stopword merupakan kata-kata penghubung seperti "yang", "dan", "dari", dan lain sebagainya. Stopword dihilangkan karena dapat mengganggu analisis selanjutnya dengan frekuensi kemunculannya yang cukup banyak. 
Tahapan preprocessing yang dilakukan terhadap variabel user description, username, dan display name hanya mencakup langkah (4) sampai (6).

2. Analisis Deskriptif

Metode analisis deskriptif digunakan untuk melihat pola dan gambaran umum dari data, seperti volume tweet per-hari dan per-jam, tren percakapan sebelum dan ketika sensus penduduk online berlangsung, persentase orang BPS maupun nonBPS yang terlibat dalam percakapan mengenai topik tersebut, dan persentase jumlah tweet yang dikirimkan oleh orang BPS dan nonBPS. Volume tweet per-hari dan volume tweet per-jam divisualisasikan dengan menggunakan diagram batang, sedangkan garis tren divisualisasikan dengan menggunakan diagram garis.

String matching digunakan untuk membagi pengguna menjadi pengguna BPS dan nonBPS. Selanjutnya string matching digunakan untuk mengetahui persentase orang BPS (mencakup seluruh mahasiswa Politeknik Statistika STIS) dan nonBPS yang membuat tweet atau meretweet tentang sensus penduduk 2020 dan persentase jumlah tweet yang dikirimkan orang BPS dan nonBPS. String matching dilakukan dalam 2 tahap. Tahap pertama, matching dilakukan dengan mencocokkan antara user description dan display name dengan kata kunci yang berhubungan dengan BPS dan STIS. Pencocokan string dilakukan dengan memecah user description dan display name ke dalam bentuk unigram, bigram, dan trigram, kemudian mencocokkan masing-masing n-gram dengan kata kunci. Jika kata kunci ditemukan dalam user description maupun display name, maka dapat disimpulkan bahwa akun merupakan milik orang BPS dan diberi label 1. Jika kata kunci tidak ditemukan, maka disimpulkan bahwa akun bukan milik orang BPS dan diberi label 0. Tahap kedua, matching dilakukan dengan mencocokkan antara username dan display name dari akun twitter yang mengirim tweet tentang sensus penduduk 2020 dengan database nama pegawai BPS dan nama mahasiswa Politeknik Statistika STIS. Langkah-langkah dalam melakukan name matching mengacu pada penelitian Branting (2003) yaitu (1) normalisasi atau preprocessing data; (2) similarity assesment atau penilaian kesamaan menggunakan algoritma LCS untuk menentukan rasio kemiripan dua buah string nama, jika rasio kemiripan lebih dari atau sama dengan 80 persen maka dapat disimpulkan bahwa pengguna merupakan orang BPS; dan (3) pendekatan wordby-word secara simetris, dimana kedua nama dikatakan match jika setiap string pada nama yang lebih pendek cocok dengan string dalam nama yang lebih panjang, misalnya nama 'ahmad fauzi akan dianggap match dengan 'ahmad a. fauzi' dan sebaliknya, namun 'ahmad a. fauzi' dianggap tidak match dengan 'ahmad b. fauzi.

3. Wordcloud

Visualisasi wordcloud digunakan untuk menggambarkan 100 kata yang sering muncul pada tweet mengenai sensus penduduk 2020.

4. Analisis Sentimen

Analisis sentimen dilakukan dengan metode lexicon based dengan menggunakan kamus kata dan program SentiStrength yang terdapat pada penelitian Wahid dan Azhari (2016). Metode lexicon based mencocokan kalimat terhadap kamus kata yang kemudian menghasilkan nilai positif dan negatif dengan rentang antara 1 sampai 5 . Nilai terbesar dalam satu kalimat menjadi nilai akhir sentimen. Selanjutnya, hasil analisis dievaluasi dengan menghitung nilai presisi, recall, dan F1-score untuk masing-masing kelas sentimen.

5. Social Network Analysis

Social Network Analysis digunakan untuk melihat retweet network pada topik sensus penduduk 2020. Data yang digunakan yaitu username yang melakukan retweet dan username yang di-retweet yang berasal dari data streaming. Pengguna twitter menjadi node dan hubungan antar pengguna menjadi edge. Semakin besar ukuran node menunjukkan bahwa user tersebut semakin sering di-retweet.

\title{
HASIL DAN PEMBAHASAN
}

\author{
ANALISIS DESKRIPTIF
}




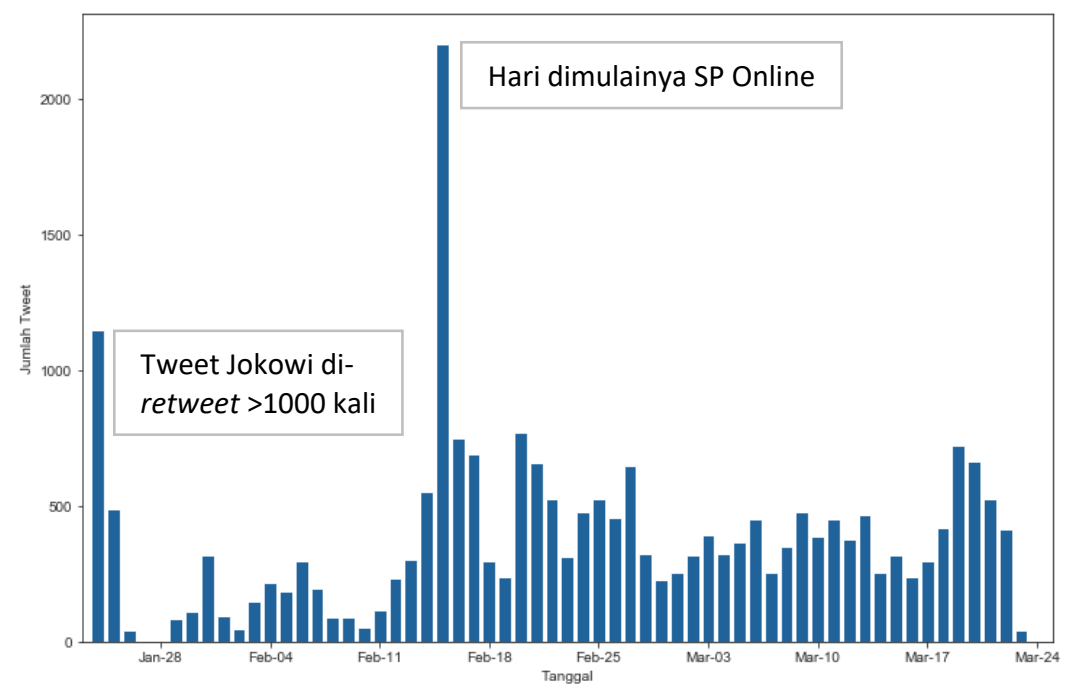

Gambar 1. Diagram Batang Volume Tweet per-Hari.

Berdasarkan gambar di atas, dapat dilihat bahwa volume tweet per hari tidak merata. Pada tanggal 24 Januari 2020, jumlah tweet mencapai 1148 tweet. Hal ini disebabkan karena pada hari itu akun presiden Jokowi mengirimkan tweet berisi ajakan mengikuti sensus penduduk online dan di-retweet hingga 1000 kali. Pada tanggal 15 Februari 2020, jumlah tweet meningkat hingga lebih dari 2000 tweet. Hal ini disebabkan karena tanggal 15 Februari 2020 merupakan hari dimulainya sensus penduduk online. Tweet kembali menurun setelah tanggal 15 Februari 2020. Akan tetapi, jumlah tweet per-hari seringkali berjumlah lebih dari 250 tweet sejak dimulainya sensus penduduk online. Berbeda dengan sebelum berlangsungnya sensus penduduk online, jumlah tweet seringkali tidak mencapai 250 tweet per-hari. Dari hasil tersebut dapat disimpulkan bahwa jumlah tweet akan mengalami peningkatan yang signifikan ketika kegiatan akan berlangsung dan ketika terdapat tokoh publik yang menginformasikan tentang kegiatan tersebut, seperti presiden.

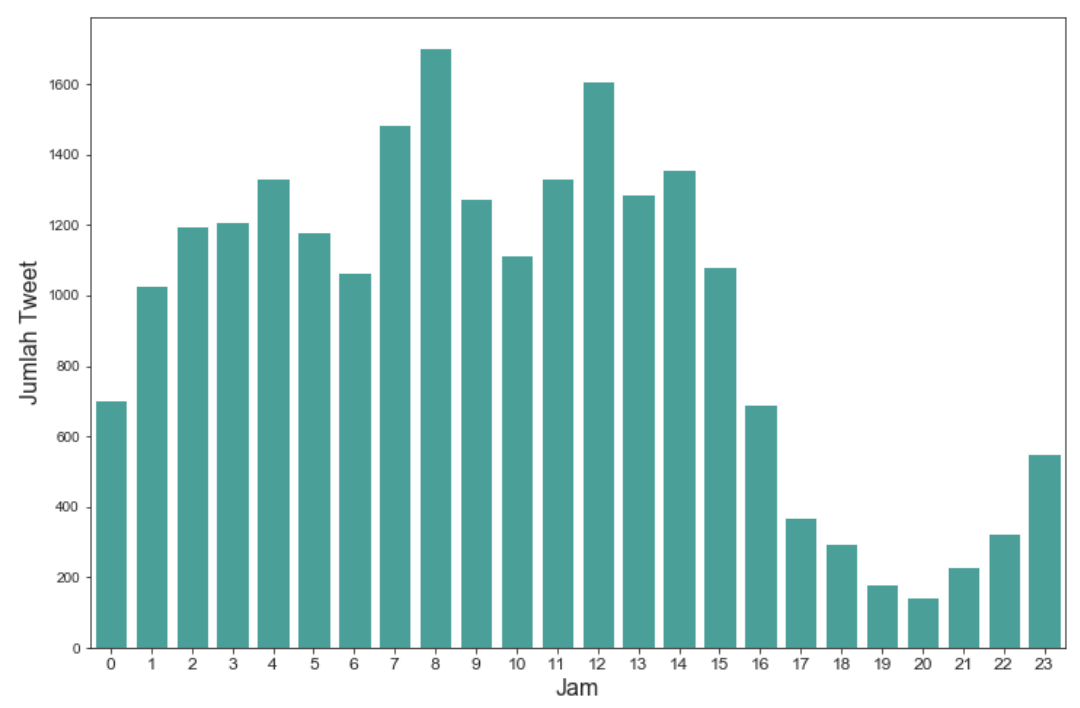

Gambar 2. Diagram Batang Volume Tweet per-Jam.

Diagram batang di atas merupakan volume tweet per-jam yang diambil dari data streaming sejak tanggal 24 Januari 2020 sampai dengan 23 Maret 2020. Grafik di atas menunjukkan bahwa rata-rata pembicaraan tentang sensus penduduk mengalami peningkatan jumlah mulai pukul 24.00 WIB dan kembali mengalami penurunan mulai pukul 13.00 WIB. Namun, meskipun mengalami penurunan jumlah, pada pukul 1 siang jumlah tweet masih terbilang cukup banyak. Puncak pembicaraan terjadi pada pukul 8 pagi dan 12 siang. Pukul 8 pagi merupakan waktu baru dimulainya jam kerja. Pukul 12 siang merupakan jam istirahat untuk pekerja dan pelajar, sehingga pada jam tersebut banyak orang yang membuka media sosialnya. Dilansir dari idntimes.com, 
waktu terbaik untuk posting di twitter adalah pada pukul 12 sampai 3 sore dan tidak disarankan untuk memposting pada pukul 8 malam.

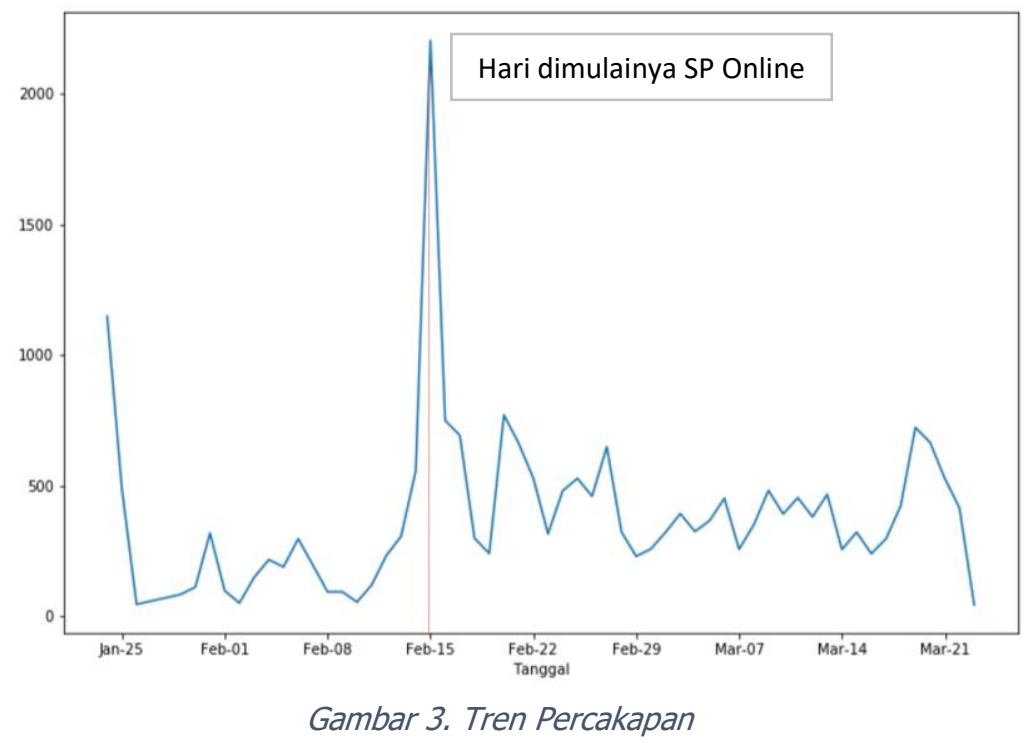

Gambar di atas menunjukkan tren tweet tentang sensus penduduk 2020. Jumlah tweet terus berfluktuasi dari tanggal 24 Januari sampai 23 Maret 2020. Pada tanggal 14 Februari 2020 jumlah tweet meningkat menjadi 556 tweet. Pada hari pertama sensus penduduk online diselenggarakan terdapat 2.204 tweet, kemudian tweet mengalami penurunan. Meskipun mengalami penurunan jumlah, sejak sensus penduduk online berlangsung, jumlah tweet tentang sensus penduduk selalu lebih banyak dari sebelum berlangsungnya sensus penduduk online.

String matching kemudian dilakukan untuk mendapatkan hasil persentase jumlah orang BPS dan nonBPS yang mengirimkan tweet tentang sensus penduduk dan persentase jumlah tweet yang dikirimkan orang BPS dan nonBPS. Hasil yang diperoleh adalah sebagai berikut:

1. Matching dengan user description dan display name

Proses pencocokan string yang pertama menggunakan user description dan display name. Pencocokan dilakukan dengan melakukan pengecekan apakah kata kunci yang berhubungan dengan BPS terdapat di dalam user description dan display name. Hasil yang diperoleh menunjukkan bahwa dari 12.234 akun terdapat 149 akun yang memiliki kata kunci yang berhubungan dengan BPS. Selanjutnya, matching dilanjutkan dengan menggunakan username dan display name terhadap 12.055 akun lainnya.

2. Matching dengan username dan display name

Matching dilakukan terhadap akun yang tidak mengandung kata kunci yang berhubungan dengan BPS. Matching antara username dan display name dengan database nama hanya dapat mendeteksi akun-akun twitter yang menggunakan nama aslinya, sehingga user yang tidak menggunakan nama aslinya tidak dapat dideteksi apakah merupakan orang BPS atau bukan dan user dianggap sebagai user nonBPS.

Setelah keseluruhan proses matching selesai dilakukan, selanjutnya dilakukan penghitungan persentase antara orang BPS dan nonBPS yang membuat tweet atau me-retweet mengenai sensus penduduk 2020 dan persentase jumlah tweet yang dibagikan oleh orang BPS dan nonBPS dan diperoleh hasil sebagai berikut: 


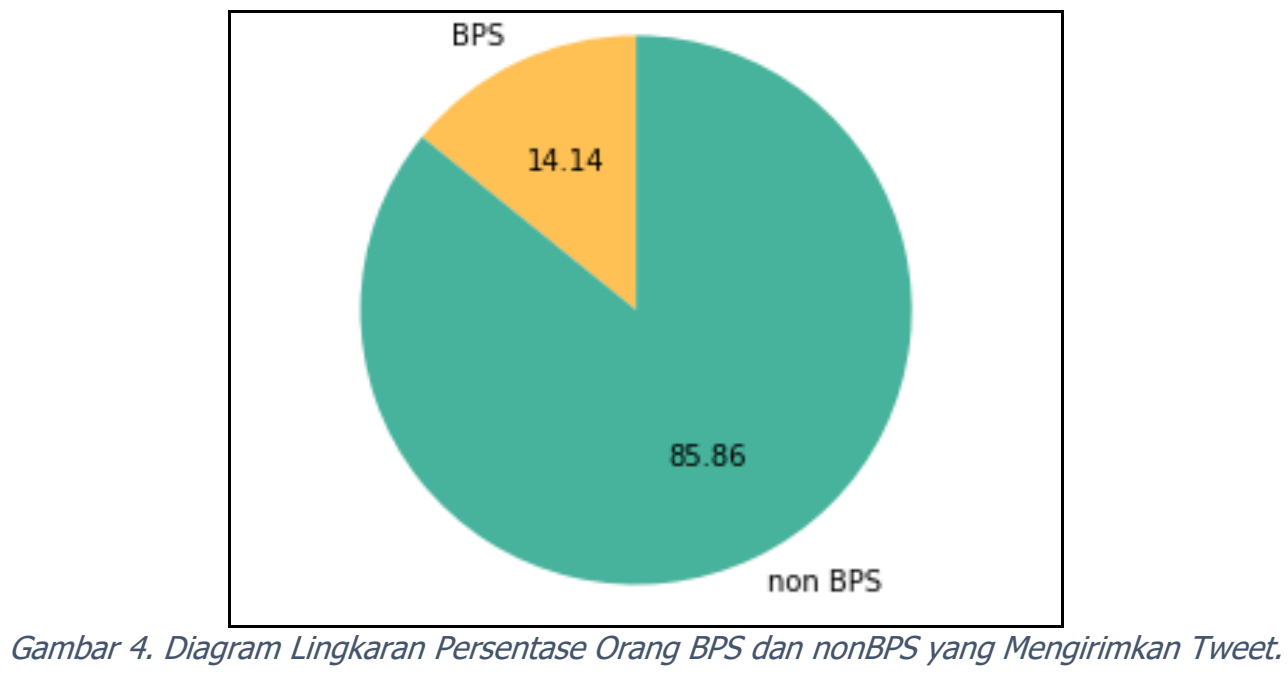

Diagram lingkaran di atas menunjukkan persentase orang BPS dan nonBPS yang berpartisipasi dalam tweet yang membahas Sensus Penduduk 2020. Hasil yang diperoleh yaitu 85,86 persen dari keseluruhan user yang membuat tweet mengenai Sensus Penduduk 2020 adalah nonBPS dan sisanya 14,14 persen merupakan orang BPS.

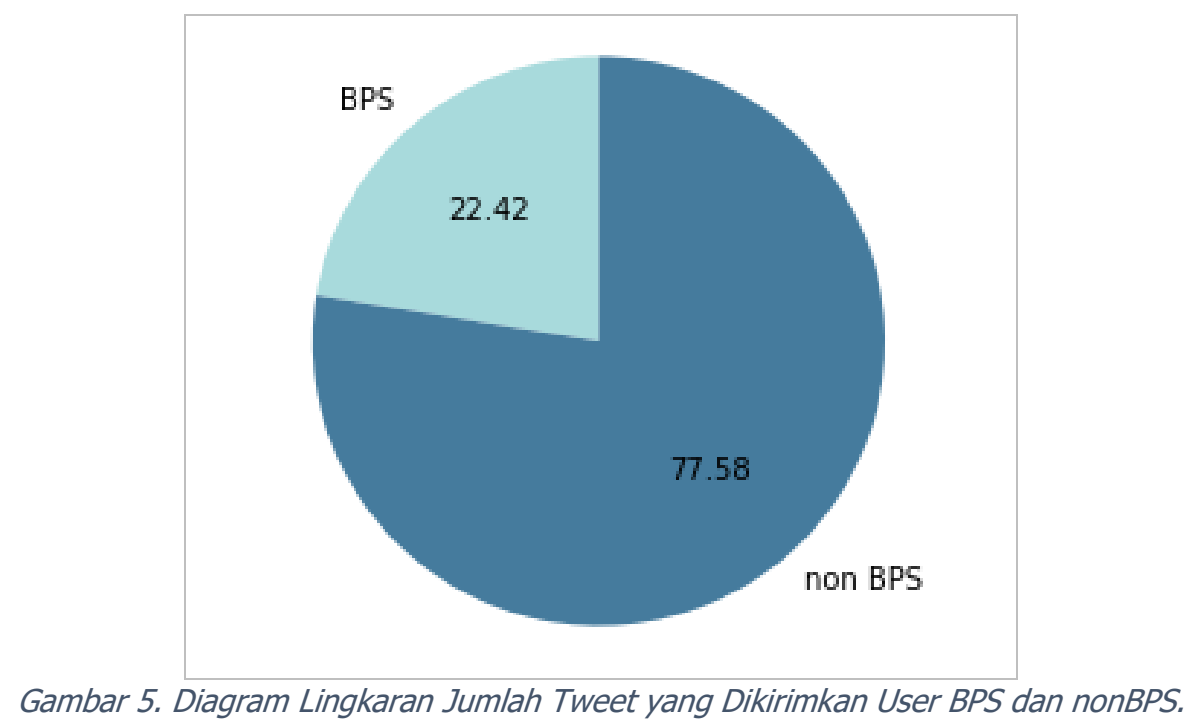

Diagram lingkaran di atas menunjukkan persentase jumlah tweet yang dibagikan oleh orang BPS dan nonBPS. Sebanyak 77.58 persen dari keseluruhan tweet dibagikan oleh user nonBPS, dan sisanya 22,42 persen tweet dibagikan oleh user BPS.

Kedua diagram lingkaran di atas menunjukkan bahwa partisipasi masyarakat diluar lingkup BPS terhadap kegiatan sensus penduduk 2020 cukup tinggi. Hal ini ditunjukkan dengan persentase user nonBPS sebesar 85,86 persen serta jumlah tweet yang berasal dari user tersebut sebesar 77,58 persen, lebih banyak dibandingkan user BPS.

\section{WORDCLOUD}

Selain gambaran mengenai pola percakapan seperti volume tweet dan tren sebelum dan ketika berlangsungnya sensus penduduk online, dapat diketahui juga kata-kata yang sering muncul pada tweet yang membahas tentang sensus penduduk 2020. Wordcloud merupakan representasi teks secara visual. Semakin besar ukuran huruf dalam wordcloud, menunjukkan semakin sering kata tersebut muncul dalam teks. 


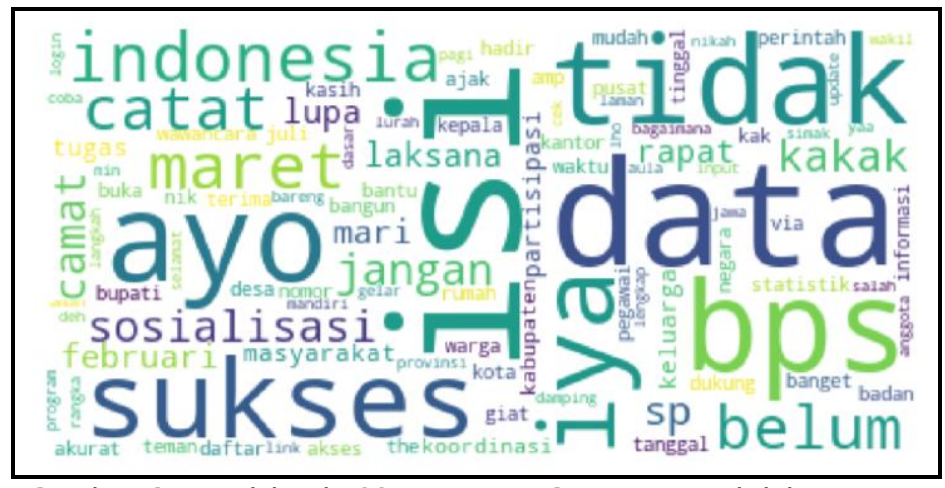

Gambar 6. Wordcloud 100 Kata yang Sering Muncul dalam Tweet.

Dari gambar di atas dapat dilihat bahwa kata yang paling sering muncul adalah kata 'isi'. Kata tersebut muncul sebanyak 2.432 kali. Hal ini dikarenakan banyak tweet yang berisi ajakan untuk ikut mengisi sensus penduduk online dan tweet yang berisi informasi bahwa pengirim tweet sudah mengisi sensus penduduk online. Contoh dari tweet tersebut seperti "yuk, ikut berpartisipasi mengisi sensus secara online melalui: bps.go.id, teman-teman jangan lupa isi data kalian disini ya supaya data kalian tercatat dan update".

\section{ANALISIS SENTIMEN}

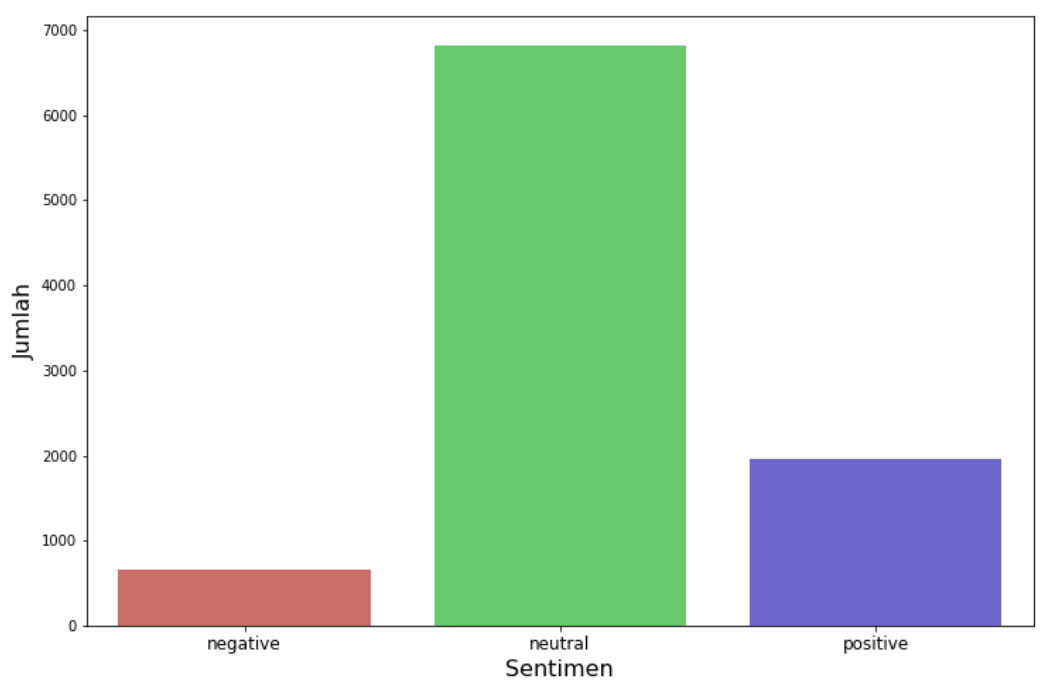

Gambar 7. Diagram Batang Hasil Analisis Sentimen.

Diagram batang di atas menunjukkan jumlah masing-masing kelas sentimen pada data tweet yang membahas Sensus Penduduk 2020. Hasil yang diperoleh terdapat sebanyak 1.959 tweet memiliki sentimen positif, 663 tweet memiliki sentimen negatif, dan 6.819 tweet memiliki sentimen netral. Tweet paling banyak tergolong ke dalam kelas netral karena topik yang dibahas adalah informasi mengenai berlangsungnya kegiatan sensus penduduk, seperti tanggal mulai dan berakhirnya sensus penduduk, kuis sensus penduduk, jawaban pengguna twittter terhadap kuis sensus penduduk, dan berita mengenai orang-orang penting, seperti presiden, menteri, dan bupati atau walikota yang sudah berpartisipasi dalam sensus penduduk online. Tweet negatif banyak berisi keluhan orang yang gagal mengisi sensus penduduk online dikarenakan website yang susah dibuka, tidak bisa melakukan input captcha, sinyal yang kurang stabil, tidak mengerti isian apa yang harus diisikan, dan keluhan karena terlalu banyak dokumen yang perlu disiapkan, seperti surat pernikahan, dan lain sebagainya. Tweet positif banyak berisi ajakan untuk mengikuti sensus penduduk online karena kemudahan yang diberikan, kekaguman terhadap sistem online, dan lain sebagainya. Berikut merupakan hasil evaluasi analisis sentimen dengan SentiStrength: 
Tabel 2. Hasil evaluasi analisis sentimen

\begin{tabular}{lccc}
\hline Kelas sentiment & \multicolumn{3}{c}{ Ukuran Evaluasi } \\
\cline { 2 - 4 } & Presisi & Recall & F1-score \\
\hline Neutral & 0,98 & 0,81 & 0,88 \\
Positive & 0,57 & 0,94 & 0,71 \\
Negative & 0,71 & 0,90 & 0,79 \\
\hline
\end{tabular}

\section{SOCIAL NETWORK ANALYSIS}

Pada penelitian ini, SNA digunakan untuk melihat hubungan antar aktor pada tweet yang membahas sensus penduduk 2020. Titik-titik pada gambar di bawah ini merepresentasikan pengguna twitter, sementara garis yang menghubungkan titik-titik tersebut menunjukkan bahwa titik-titik tersebut memiliki hubungan. Semakin besar ukuran node menunjukkan bahwa semakin sering node tersebut di retweet oleh node lain. Warna biru menunjukkan pengguna twitter yang me-retweet akun jokowi, warna oranye menunjukkan pengguna twitter yang me-retweet akun bps_statistics, dan warna hijau menunjukkan pengguna twitter yang me-retweet akun sandalista1789. Akun sandalista1789 merupakan akun komunitas yang seringkali mengirimkan opini dan komentar-komentar terhadap tweet yang dikirimkan oleh organisasi pemerintah maupun politisi, selain itu akun tersebut juga seringkali mengirimkan tweet yang berkaitan dengan beritaberita tentang kebijakan pemerintah.

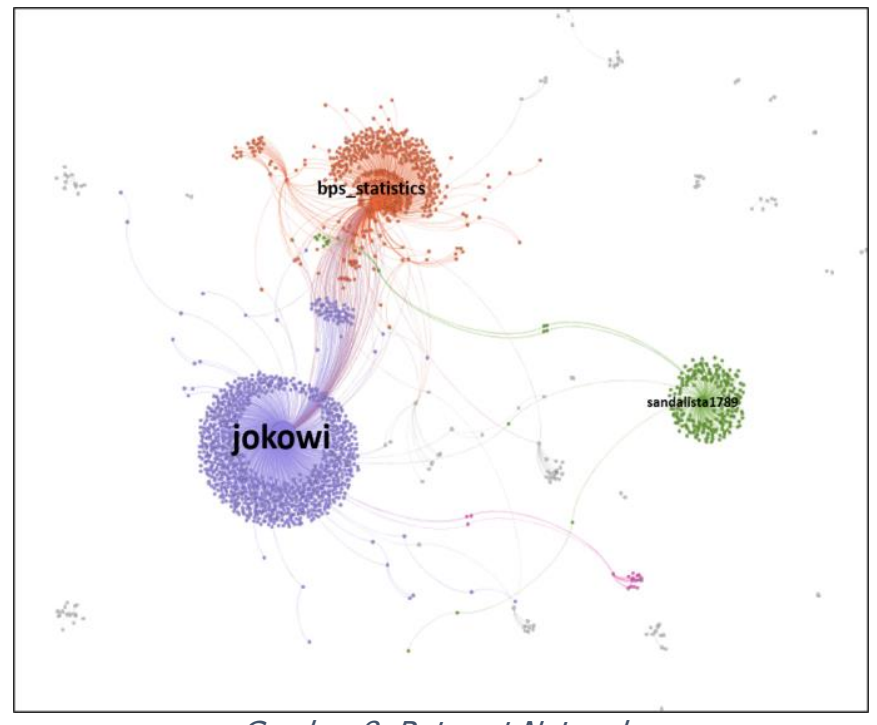

Gambar 8. Retweet Network.

Dari hasil di atas, dapat diketahui pula 10 akun yang paling banyak di retweet oleh akun lain. Akun-akun tersebut, yaitu: (1) jokowi; (2) bps_statistics; (3) sandalista1789; (4) IndonesiaBaikId; (5) Bpsprovjateng; (6) Uki23; (7) KemnakerRI; (8) DiskominfoNtn; (9) Bpsprovinsibali; dan (10) DKIJakarta. Kesepuluh akun tersebut merupakan akun yang sudah diverifikasi oleh twitter dengan jumlah followers lebih dari 10.000 orang. Akun sandalista1789 merupakan akun komunitas yang sering mengirimkan tweet yang berisi opini terhadap kebijakan pemerintah dan mengirimkan tweet yang berkaitan dengan berita-berita tentang kebijakan pemerintah. Akun IndonesiaBaikId merupakan akun yang berada di bawah naungan Kementrian Kominfo. Akun Uki23 merupakan akun pribadi yang sering mengirimkan tweet berisi opini-opini. DiskominfoNtn merupakan akun milik Dinas Komunikasi dan Informatika Kabupaten Natuna. Tujuh dari sepuluh akun di atas merupakan akun lembaga pemerintah, dua akun pribadi, dan satu akun komunitas.

Hasil dari analisis ini dapat memberikan manfaat untuk BPS, yaitu dalam menyebarkan informasi kegiatan-kegiatan selanjutnya BPS dapat bekerja sama dengan akun-akun yang paling sering di-retweet di atas agar kegiatan yang diselenggarakan dapat semakin dikenal publik. 


\section{KESIMPULAN}

Tweet yang diperoleh menunjukkan tren yang fluktuatif. Jumlah tweet meningkat tajam ketika sensus penduduk online akan berlangsung dan ketika Presiden Jokowi mengirimkan tweet tentang sensus penduduk. Puncak pembicaraan terjadi pada pukul 8 pagi dan 12 siang, sehingga disarankan untuk mengirimkan tweet pada waktu-waktu tersebut. Sebagian besar tweet bersentimen netral, yang berarti tweet tersebut berisi informasi mengenai berlangsungnya sensus penduduk online, kuis seputar sensus, dan berita mengenai orang penting yang telah berpartisipasi pada sensus penduduk online. Proporsi pengguna yang membuat tweet atau meretweet tentang sensus penduduk 2020 didominasi oleh pengguna nonBPS yaitu sebesar 85,86 persen dan 14,14 persen sisanya adalah orang BPS. Hal tersebut menunjukkan bahwa partisipasi masyarakat di luar lingkup BPS terhadap kegiatan sensus penduduk 2020 sudah cukup tinggi. Terdapat 3 akun yang paling sering di retweet, yaitu akun presiden Jokowi, akun Badan Pusat Statistik, dan akun sandalista1789. Akun sandalista1789 merupakan akun komunitas yang seringkali mengirimkan opini atau komentar terhadap tweet yang dikirimkan oleh organisasi pemerintah maupun politisi. Ketiga akun telah diverifikasi oleh twitter dan memiliki followers lebih dari 10.000 orang. Dari sepuluh akun yang paling banyak di retweet, 7 diantaranya merupakan akun lembaga pemerintah, 2 akun komunitas, dan 1 akun pribadi. Hal ini menunjukkan bahwa akun pemerintah berperan penting dalam menyebarkan informasi terkait suatu kegiatan. Selain itu, akun komunitas dan akun pribadi yang sering memberikan opini berkaitan dengan kebijakan pemerintah juga memiliki peran penting dalam penyebaran informasi. Dalam menyebarkan informasi kegiatan-kegiatan selanjutnya, BPS dapat bekerja sama dengan akun-akun tersebut agar kegiatan yang diselenggarakan dapat semakin dikenal publik.

\section{DAFTAR PUSTAKA}

Branting, K. (2003). A Comparative Evaluation of Name-Matching Algorithms. The 9th International Conference, 224-232.

Christen, P. (2006). A Comparison of Personal Name Matching: Techniques and Practical Issues. The Second International Workshop on Mining Complex Data, 1-15.

Idntimes.com. Waktu Terbaik dan Terburuk untuk Posting di Media Sosial, Ingat-Ingat!. Cited in https://www.idntimes.com/tech/trend/arifgunawan/waktu-terbaik-dan-terburuk-untuk-posting-dimedia-sosial/4. [21 Juni 2020]

Kompas.com. (27 November 2019). 2020, BPS Lakukan Sensus Penduduk secara Online. Cited in https://nasional.kompas.com/read/ 2019/11/27/17070831/2020-bps-lakukan-sensus-penduduk-secaraonline?source=autonext. [20 Desember 2019]

Nasional.kompas.com. (17 Februari 2020). BPS Akui Sosialisasi Sensus Penduduk 2020 Belum Sampai ke Akar Rumput. Cited in https://nasional.kompas.com/read/2020/02/17/13044271/bps-akui-sosialisasisensus-penduduk-2020-belum-sampai-ke-akar-rumput?page=all. [15 Agustus 2020]

Pedersen, S. \&. (2015). Backchannel Chat: Peaks and Troughs in a Twitter Response to Three Televised Debates during the 2014 Scottish Independence Referendum Campaign. CeDEM15 Conference for E-Democracy and Open Governement.

Statista.com. (24 Juli 2020). Countries with the most twitter users 2020. Cited in https://www.statista.com/statistics/242606/number-of-active-twitter-users-in-selected-countries/. [12 Agustus 2020]

Steketee, M. (2015). Social Network Analysis. International Encyclopedia of the Social \& Behavioral Sciences, 2nd edition, Volume 22, 461-467.

Takeichi, Y. e. (2014). Twitter as Social Sensor: Dynamics and Structure in Major Sporting Events. Proceedings of the Fourteenth International Conference on the Synthesis and Simulation of Living Systems, 1-7.

Thelwall, M. (2013). Heart and soul: Sentiment strength detection in the social web with sentistrength. Cyberemotions. 1-14.

Wahid, D. \& Azhari (2016). Peringkasan Sentimen Esktraktif di Twitter Menggunakan Hybrid TF-IDF dan Cosine Similarity. IJCCS, Vol. 10, No. 02, 207-218. 
Walck, P. E. (2013). Book Review Twitter: Social Communication in the Twitter Age. International Journal of Interactive Communication Systems and Technologies, 3(2), 66-69.

Wang, D., Abdelzaher, T., \& Kaplan, L. (2015). Chapter 2 - Social Sensing Trends and Applications. In D. Wang, T. Abdelzaher, \& L. Kaplan, Social sensing (pp. 13-20). Elsevier Inc.

Wu, C.H., \& Li, T.Y. (2016). Social Sensor: An Analysis Tool For Social Media. International Journal of Electronic Commerce Studies Vol. 7, No. 1, 77-94. 